\title{
A novel alkali-surfactant for optimization of filtercake removal in oil-gas well
}

\author{
Kevin Nsolloh Lichinga ${ }^{1,2} \cdot$ Amos Luanda $^{3} \cdot$ Mtabazi Geofrey Sahini $^{3}$
}

Received: 9 September 2021 / Accepted: 20 December 2021 / Published online: 13 January 2022

(c) The Author(s) 2022

\begin{abstract}
The main objective of this study is to improve the oil-based filtercake removal at the wellbore second interface through chemical method. The reductions in near-well permeability, bonding strength at wellbore second interface and acidizing treatment are the critical problems in oilfield upstream operations. One of the major causes has been identified as drilling fluid filtrate invasion during the drilling operations. This as result leads to near-well reduction in-flow capacity due to high drawdown pressure and wellbore instability. A number of chemical methods such as enzymes, acids, oxidizers, or their hybrids, have been used, however, due to the presence of a number of factors prior to its removal, there are still many challenges in cleaning oil-based filtercake from the wellbore surface. There is a need for development an effective method for improving oil-based filtercake removal. This study presents a novel Alkali-Surfactant (KV-MA) solution developed in the laboratory to optimize the filtercake removal of oil-gas wellbore. The Reynold number for KV-MA solution was found to be 9,068 indicating that turbulent flow regime will dominate in the annulus which enhances the cleaning efficiency. The wettability test established that, contact angle of $14^{\circ}$ was a proper wetting agent. The calculated cleaning efficiency was $86.9 \%$, indicating that it can effectively remove the oil-based filtercake. $\mathrm{NaOH}$ reacts with the polar components in the oil phase of the oil-based filtercake to produce ionized surface-active species; hence reducing the Interfacial Tension. Surfactant quickens the diffusion of ionized species from the interface to the bulk phase.
\end{abstract}

Keywords Cement-formation interface $\cdot$ Oil-based filtercake $\cdot$ Alkali-surfactant $\cdot$ Viscosity $\cdot$ Cleaning efficiency $\cdot$ Reynold number

Nomenclature

APG-1416 Alkyl Polyglucoside which contains a number of carbons from 14 to 16 in its hydrocarbon part

API American Petroleum Institute

Kevin Nsolloh Lichinga

kevinnsolloh@gmail.com

Mtabazi Geofrey Sahini

mtabazi.sahini@udom.ac.tz

1 Department of Engineering Development, Tanzania Industrial Research and Development Organization (TIRDO), P.O Box 23235, Dar es Salaam, Tanzania

2 Department of Petroleum Engineering, Faculty of Earth Resources for Oil Well Cement Research and Testing, China University of Geosciences, No. 388, Lumo Road, Hongshan District, Wuhan 430074, PR China

3 Department of Chemistry, College of Natural and Mathematical Sciences, The University of Dodoma (UDOM), P. O. Box 259, Dodoma, Tanzania

\begin{tabular}{|c|c|}
\hline Fig & Figure \\
\hline gpm & Gallon per minute \\
\hline KV-MA & $\begin{array}{l}\text { Designed chemical wash for oil-based filter- } \\
\text { cake removal }\end{array}$ \\
\hline OBM & Oil-Based Mud \\
\hline ppg & Pound per gallon \\
\hline SWB & Simulated Wellbore \\
\hline WBM & Water-Based Mud \\
\hline TIRDO & $\begin{array}{l}\text { Tanzania Industrial Research and Develop- } \\
\text { ment Organization }\end{array}$ \\
\hline UDOM & University of Dodoma \\
\hline YP & Yield Point \\
\hline AV & Apparent Viscosity \\
\hline PV & Plastic Viscosity \\
\hline
\end{tabular}

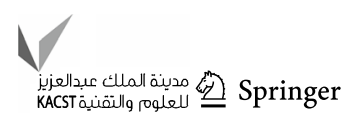




\section{Introduction}

The successful filtercake removal near the wellbore in horizontal oil-gas wells has been a critical issue in drilling and well completion operations as failure to effectively remove it would result to and reduction of permeability hence low as reported in various field cases (Leschi et al. 2006; Ding et al. 2006; Almond et al. 1995). In addition, the existing filtercake might lead to poor cementing job by preventing the cement material to effectively react with rock material of formation to form a strong bond at the interface between cement sheath and formation hence leading to poor zonal isolation. More than 8,000 wells in the Gulf of Mexico and 18,000 of the wells in Alberta, Canada have been exhibiting have leak related problem (Federal 2010; Agbasimalo and Radonjic 2014; Kiran et al. 2017). Moreover, during acidizing treatment of formation to make the formation more productive, if oil-based contaminants enter the formation interval and are not removed therefrom the effectiveness of the acidizing treatment can be substantially reduced (Yuan et al. 2002; Chan et al. 1998). Thus, the cost of remedial action for any of the above-mentioned failures can be substantial in both onshore and offshore well operations.

A number of cleaning methods particularly chemical methods such as enzymes, acids, oxidizers, or their hybrids, have been used (Nasr-El-Din and Samuel 2007; Nasr-ElDinet al. 2004, 2005; Malone et al. 2000; Zain and Sharma 1999; Wang et al. 2001). However, due to the presence of a number of factors prior to its removal, there are still many challenges in cleaning oil-based filtercake from the wellbore surface. Oxidizing agents and acidic materials are very reactive, whereby they may lead to improper cleaning of filtercake residue, since minerals such as illites in sandstone reservoir are highly sensitive to acids. This would cause formation damage near the wellbore. Enzymes have difficulty degrading starch and xanthan polymers under certain conditions (heterogeneous formations with high permeability streaks), necessitating large volumes of treatment fluid. Furthermore, enzyme has a difficult time dissolving calcium carbonate particle (Al-Otaibi et al. 2004a, b).

In addition, a number of challenges are still existing in cleaning of oil-based filtercake from the wellbore surface due to the presence of a number of factors prior to its removal. One of the factors is wettability whereby the filtercake near-wellbore should be changed from oil-wet phase to water-wet phase. This is accomplished by incorporating a large number of volumes of mutual solvents, and surfactant in a supporting fluid. As a result, the oil well drilling and completion operations by using oil-based fluid tend to be time consuming and expensive compared to the conventional treatment. (Khalid et al. 2009).
A drilling fluid, according to the American Petroleum Institute (API), is any fluid that is circulated in the borehole to aid in the execution of a cost-effective and efficient drilling operation that results in a stable and gauged borehole to the targeted depth with minimum possible damage to prospective formations (Gandhi and Sarkar 2016). They are divided into two categories: water-based drilling fluids and oil-based drilling fluids. They act as coolant, lubricant, cleaner, carrier, formation pressure control, and enhance the function of the drill string and tools in the hole (Drilling Muds 2015). Oil-based fluids are thought to be used in formation where water-based fluid (WBFs) cannot withstand certain environmental conditions, such as high temperatures where WBF may degrade thermally (Fontenot and Simpson 1998).

During drilling operations, the filtrate from the drilling fluids enters the formation due to differential pressure between the wellbore and formation rock. As a result, less solid particulates collect at the surface of the wellbore surface, forming a filtercake ranging in size from 2 to $5 \mathrm{~mm}$ (Mushtaq 2013). However, the typical rational real thickness of oil-based and water-based filtercake should be between 0.5 and $1.5 \mathrm{~mm}$ (Ladva et al. 2004, 2005). For less stable wellbores, this acts as a wellbore stabilizer, preventing the formation fluids from entering the wellbore (Rostami and Nasr-EI-Din 2010).

Upon well completion operations, the penetrated filtercake at the near-wellbore formation tends to alter the nearwell flow properties, resulting in significantly reduced well productivity. Furthermore, the presence of such filtercake prevents the formation of strong bonds between cement and rock, resulting in weak points where failure can occur (Lichinga et al. 2020). The most important practice during oil-gas well drilling and completion designs for optimizing oilfield development is the effective cleanup of oil-based filtercake from the wellbore (Al-Otaibi et al. 2010).

When designing specific treatment fluids, several factors must be considered. These include the type of drilling fluid (mud), salinity, temperature, and reservoir, as well as compatibility between treatment fluid, formation fluid and drilling fluids, as incompatibility could result in deposition/precipitation, resulting in formation/reservoir damage (Moore et al. 1996; Malone et al. 2000) and lowered well productivity.

The interaction between oily phase and alkaline is of utmost important in the cleaning process of oily-phase attacked materials. It is extensively believed that the effect of alkaline on decreasing the interfacial tension (IFT) is in the sense that alkaline tends to react with the polar components in oil to form surface-active agents (Guo et al. 2005). These 
agents adsorb at the interface to lower the oil/water $(\mathrm{O} / \mathrm{W})$ IFT. The dynamic characters of IFT between oil and water are caused by the reaction and diffusion of different reagents at the interface, which can reflect the roles of different species at the $\mathrm{O} / \mathrm{W}$ interface to some extent.

Some research works (Chan et al. 1981, 1982; Chatterjee et al. 1998; Touhami et al. 1998, 2001; Rudin and Wasan $1992 \mathrm{a}, \mathrm{b})$ proposed that the dynamic behavior is caused by a time-dependent concentration of surface-active species at the interface. Acids in the oil diffuse to the $\mathrm{O} / \mathrm{W}$ interface and react with alkaline species in the aqueous phase to produce in situ surface-active species, which lower the IFT. As the reaction proceeds, more surface-active species accumulate at the interface and, hence, decreasing IFT. The ionized acids may also form soap with sodium ions in the aqueous phase at high ionic strength, which may enhance the transfer of the surfactant from the aqueous phase to oily-phase (Taylor et al. 1996) and result in increasing the IFT.

Surfactants (surface-active agents) are organic compounds with two parts: a hydrophobic tail (Burnham et al. 2013) and a hydrophilic head. Surfactants are classified into four types according to the charge on the hydrophilic head. As shown in Fig. 1, these charges are non-ionic (without any charge), anionic, cationic, and zwitterionic (carrying both negative and positive charges) (Kume et al. 2008). A surfactant's tail group is frequently composed of a short polymer chain, a long hydrocarbon chain, or a fluorocarbon chain, whereas the head group is composed of moieties such as sulfates, sulfonates, polyoxyethylene chains, carboxylates, alcohols or quaternary ammonium salts. The presence of these components determines the surface-active agents' amphiphilic nature. (Gbadamosi et al. 2019).

For the coeffect of alkaline and surfactant, it can reduce the IFT of O/W to an ultralow level (Zhang et al. 2010). Some authors suggested that the synergistic effect resulting from both alkaline and surfactant reduces the IFT more effectively (Liu et al. 2005). According to Touhami et al.

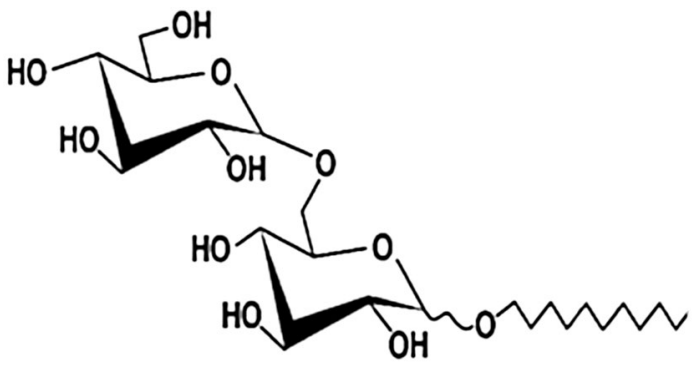

Fig. 2 Structure of Alkyl Polyglycoside (APG)

1998, the combination of alkaline and surfactant reduced IFT more rapidly than alkaline alone whereby the time required to meet the minimum IFT for $\mathrm{NaOH}$ solution was longer than that for $\mathrm{NaOH} /$ surfactant mixtures. This means that IFT is lowered more significantly by chemical reaction than by adding ready-made surfactant below the critical micelle concentration (CMC); the dynamic IFT behavior is dampened by adding the surfactant above the CMC.

The selected nonionic surfactant (Alkyl polyglycosides (APG)) is a nonionic surfactant (Fig. 2), which is synthesized from the renewable raw materials such as plant starch and fatty alcohol from coconuts. Its significance stems from the fact that it is non-toxic, mild, safe, requires little stimulation, and is completely biodegradable (Sułek et al. 2013; El-Sukkary et al. 2008; Von Rybinski and Hill 1998). It has a high potential for development in a variety of fields, including the food industry, waste treatment, medicine, and cosmetics. In recent decades, the petroleum industry has been considering it as the environmentally compatible surfactant candidates for cleaning applications (Wei et al. 2020). This is because it still remains effective at relatively high temperatures, up to about $177^{\circ} \mathrm{C}$, as well as high salinity and harness conditions found in sea water and surface brines (Lichinga et al. 2019; Chan et al. 1998, 1991).
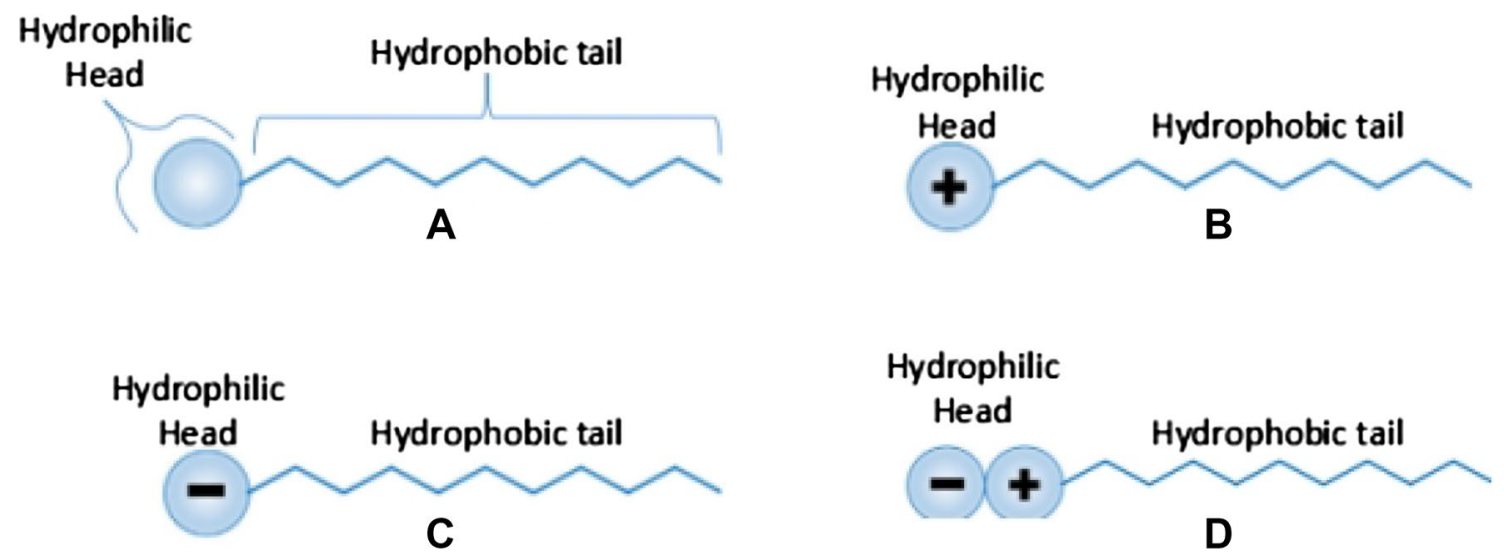

Fig. 1 Structure of surfactant, cationic (B), anionic (C), non-ionic (A), and zwitterionic (D) 
Fig. 3 Chemical wellbore cleaning of a horizontal oil well. (Zhang et al. 2020)

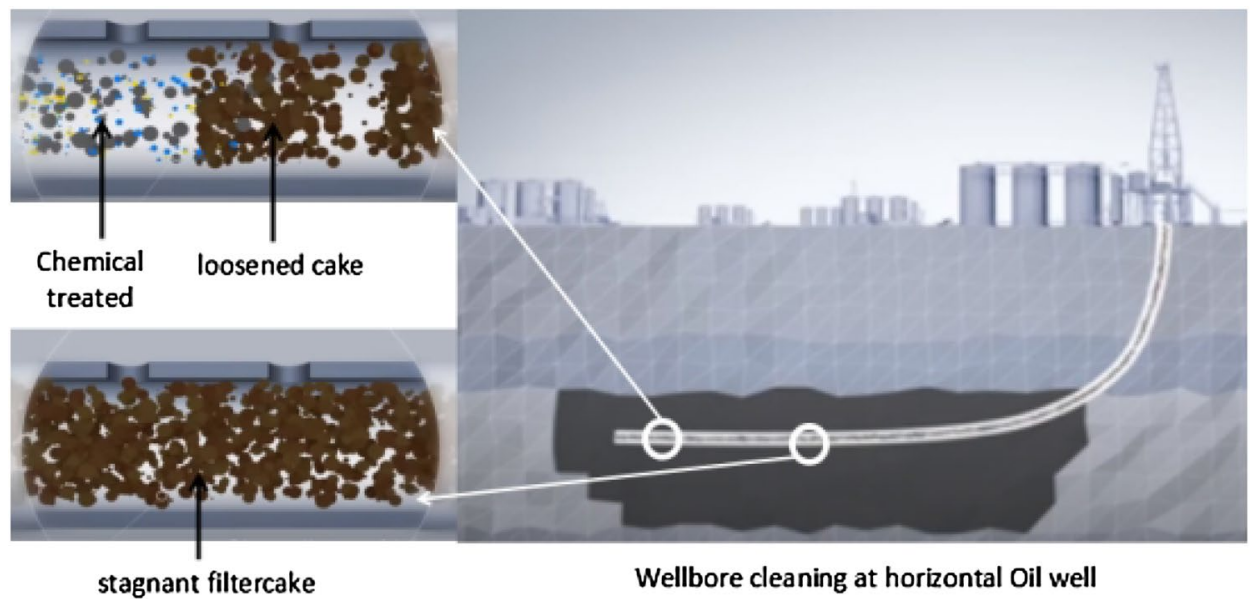

stagnant filtercake
Wellbore cleaning at horizontal Oil well
The main objective of this study is to improve the oilbased filtercake removal at the wellbore second interface through chemical method whereby an environmentally friendly solution (KV-MA) containing Alkali $(\mathrm{NaOH})$ and Non-ionic surfactant (Alkyl Polyglycoside). In this experiment, surfactant is aided by an alkali solution $(\mathrm{NaOH})$ which tends to remove the filtercake by inducing the in situ surfaceactive agent within the cake after it has penetrated inside to react with organic acid material (Fig. 3) while leaving the surface water-wet. The effective removal of filtercake in the wellbore is of utmost important because it prepares the wellbore wall surface (formation) to strongly bind with the cement slurry material through hydration process during the cementing hence improving the bond strength along the interface to ensure the long-term zonal isolation, helps to effect acidizing treatment hence sustainable well productivity.

\section{Materials and methods}

\section{Materials}

The experimental materials were taken from oilfields and some were prepared in the laboratory. They include OilBased Mud $\left(1.52 \mathrm{~g} / \mathrm{cm}^{3}\right.$ ) from Jiaoshiba Oilfield (Well DND circulated oil-based drilling fluid) containing diesel oil as base oil at $50 \%$ and other additives such as weighting material, water, emulsifying agent (surfactant), KV-MA solution containing $\mathrm{NaOH} 20 \% \mathrm{wt}$, and Alkaly Polyglycosides $15 \%$ wt (C14-C16), Defoamer 0.1\% wt (from Shandong Obot Petroleum Technology Co., Ltd. in China). Simulated wellbore (SWB) having porosity $(18 \%)$ and permeability $\left(140 \times 10^{-3} \mu^{2}\right)$ were made in the laboratory by using available quartz sand, cement and water.

\section{Instruments}

The equipment which were used during the experiment were WDW Universal testing machine (Jinan Hensgrand Instrument Co., Ltd China), TG-3060A Constant Speed Agitator (Shenyang tiger petroleum equipment manufacturing co LTD), 600 Series Servo-hydraulic Test Machines (Novatiq Pte Ltd, Singapore), The liquid density meter-YM-2 (Qingdao Hisense optical communication co LTD, specialized factory), ZNN-D6 six kinds of speed rotary viscometer (Qingdao hisense optical communication co., Itd, China), Accurate Strengthen Electronic Stirrer (Changzhou Guo Hua Electrical Equipment Co., Ltd. in China), Atmospheric Pressure Curing Chamber, TG-1280 (Shenyang tiger petroleum equipment manufacturing co LTD), Fourier Transform Infrared (FTIR) (Nicolet instrument company, USA.) and JJ-I Accurate Strengthen Electronic Stirrer (Changzhou Guo Hua Electrical Equipment Co., Ltd. in China).

\section{Methods}

\section{Preparation of simulated wellbore and filtercake}

The simulated wellbore (SWBs) having $6.5 \mathrm{~cm}$ height and diameter of $3.3 \mathrm{~cm}$ were prepared by mixing quartz sand, cement and water according to Gu et al. (2015) as shown in Fig. 4. The SWBs were sealed on one side using glass plate with butter to simulate the oil-based filtercake. Oilbased mud was injected into the borehole until it reached its maximum volume and was kept there for $4 \mathrm{~h}$ before being poured out. Using a glass rod, the formed cake was scrapped off the borehole wall to obtain the required thickness set for this study which was $0.5 \mathrm{~mm}$. 
Fig. 4 Simulated wellbore (SWB)
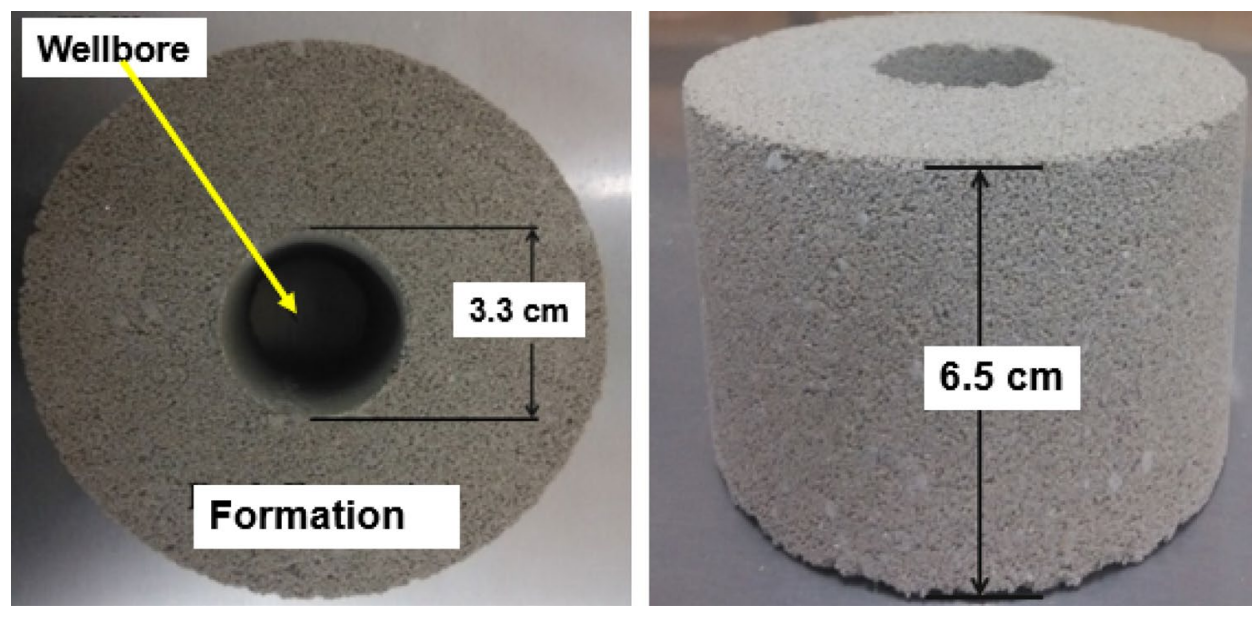

Fig. 5 Alkali-Surfactant Solution (KV-MA)

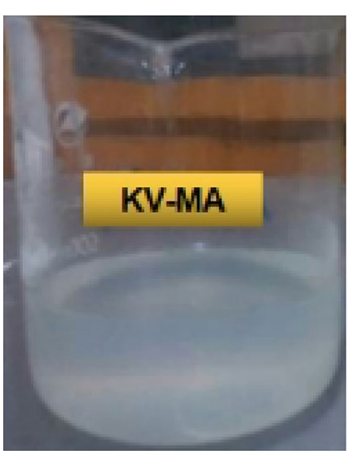

$\mu=\frac{\tau}{\gamma}$

where $\tau$ is the shear stress at the given shear rate. For Newtonian fluids $\mu$ is constant but for non-Newtonian fluids it varies with shear rate $\gamma$, thus, the viscosity computed at any given shear rate is commonly referred to as an 'apparent' or 'effective' viscosity'. Rotational Viscometer Model-35 (Fig. 7b) was used for determination of rheological properties of the KV-MA.

Apparent viscosity, shear stress $(\gamma)$, shear rate $(\tau)$ Generally, the correlation of $1 \mathrm{r} / \mathrm{min}(\mathrm{rpm})=1.703 \mathrm{~s}^{-1}$ was used to get the shear rate values. The following Eq. (2) is used to directly calculate the apparent viscosity in $\mathrm{mPa} \bullet \mathrm{s}$ or $(\mathrm{cP})$ at various rotor speeds:

$\mu=\mathrm{k} \times \mathrm{f} \times \frac{\theta}{\omega}$

In Eq. (2), $\mathrm{k}$ is the total instrument constant and $\boldsymbol{f}$ is the torsion spring factor while $\omega$ is the rotor speed (r/min). For the standard rotor-bob combination R1-B1, the value of $k$ is 300 while for standard torsion spring $\mathrm{F} 1$, the value of $f$ is 1. Therefore, the fluid viscosity in $\mathrm{mPa} \cdot \mathrm{s}$ is mathematically equivalent to the dial reading at $300 \mathrm{r} / \mathrm{min}$ of viscometer. The shear rate can directly be determined from dial reading by multiplying 0.51 depending on whether $\theta_{600}$ has been corrected.

Yield stress or point (YP) and plastic viscosity (PV) The Yield Point (YP) and Plastic Viscosity (PV) variables are obtained directly from measured readings through the direct-indicatgiven shear rate $\gamma$ is given by Eq. (1): 
ing viscometer using the Bingham plastic model, without the use of graphical plots (Lichinga et al. 2020) as shown in Eqs. (3) and (4);

$P V=\mu_{p}=\theta_{600}-\theta_{300}$

$Y P=\tau_{o}=\theta_{300}-P V=2 \theta_{300}-\theta_{600}$

the $\theta$ is the dial reading while numeric subscripts shows the rotor speed in $\mathrm{r} / \mathrm{min}$. Note $P V$ is in $\mathrm{mPa} \cdot \mathrm{s}$ and $Y P$ in $\mathrm{lb} / 100$ $\mathrm{ft}^{2}$.

Determination of flow regime A flow regime (flow pattern) is essentially a description of the flow structure, or the distribution of one fluid phase relative to another. The regime is determined by the fluid properties, the size of the conduit and the flow rates of the individual phases. The transition between laminar and turbulent flow in classic Newtonian pipe flow is widely reported to be a function of the dimensionless Reynolds number $\left(\mathrm{R}_{\mathrm{e}}\right)$. The classical definition of Re for the Newtonian fluids flowing in a pipe is

$R_{e}=\frac{\rho \times V \times D}{\mu}$

where $\rho$ is the fluid density $\left(\mathrm{lb} / \mathrm{ft}^{3}\right), \mathrm{V}$ is the average fluid velocity ( $\mathrm{ft} / \mathrm{s}$ ), $\mathrm{D}$ is the diameter of the pipe (ft), and $\mu$ is the absolute viscosity $\left(\mathrm{lb} / 100 \mathrm{ft}^{2}\right)$. Using flow rate instead of the more general velocity in conventional US Oilfield units, this equation becomes, with conversion factors Eq. (6)

$R_{e}=\frac{\rho \times Q}{\mu \times D} \times 378.92$

where $\rho$ is the fluid density (pounds per gallon), $\mathrm{Q}$ is the flow rate (gallons per minute), $\mathrm{D}$ is the diameter of the pipe or hole (in.), $\mu$ is the absolute/dynamic viscosity (centipoise) $\left(\mathrm{Fann}_{300}\right.$ dial reading); and 378.92 is the conversion factor. For annular flow, the oilfield version of Reynolds becomes

$R_{e}=\frac{\rho \times Q \times\left(d_{h}-d_{p}\right)}{\mu \times\left(d_{h}^{2}-d_{p}^{2}\right)} \times 378.92$

where $d_{h}$ is the inside diameter of the hole or prior casing (in.) and $d_{p}$ is the outside diameter of the inner pipe (in.). According to a publication of the American Petroleum Institute (API13D), the annular flow Reynolds number should be calculated by substituting the difference between the hole diameter and the pipe diameter (hydraulic diameter) for the diameter of the pipe in the classic calculation (Ramsey 2019a, b). Thus, the Reynolds numbers for annular flow is finally given by Eq. 8 below;

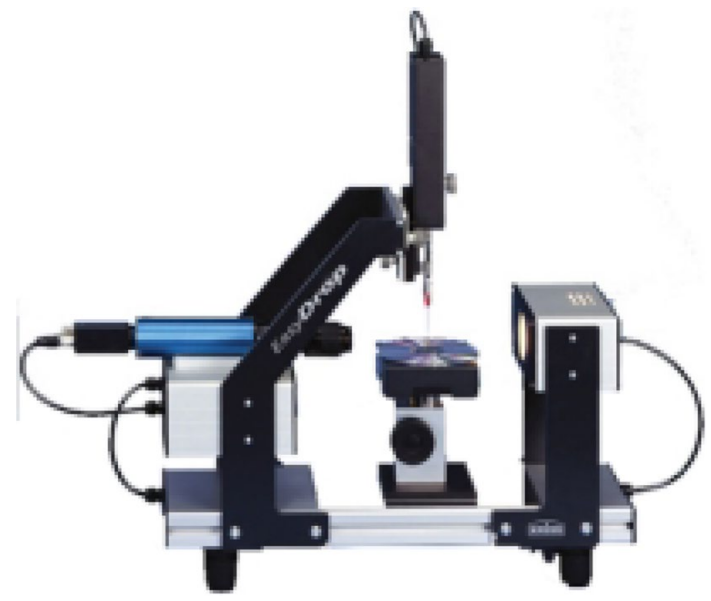

Fig. 6 Laboratory Contact angle goniometer
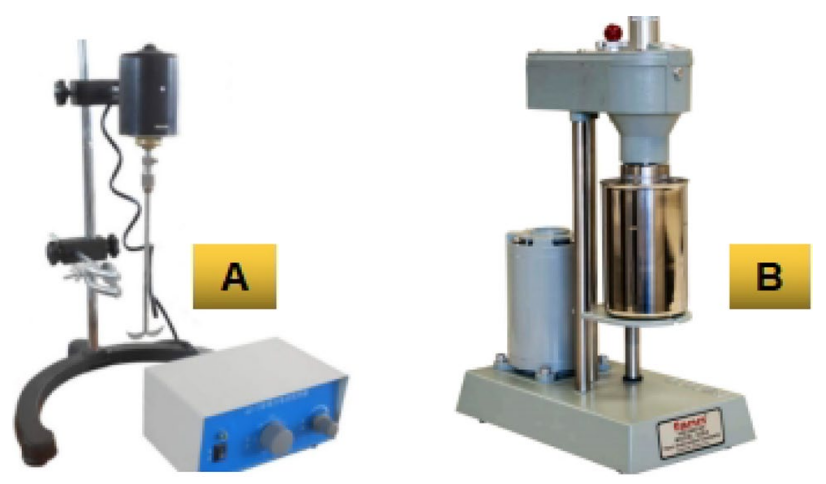

Fig. 7 Laboratory Accurate Electric Stirrer/Mixer (A) and Rotational Viscometer Model-35 (B) for determination of rheological properties of the KV-MA

$R_{e}=\frac{\rho \times Q}{\mu \times\left(d_{h}+d_{p}\right)} \times 378.92$

where the flow velocity $v$ is in $(\mathrm{ft} / \mathrm{s})$, hole diameter, $\mathrm{d}_{\mathrm{h}}$ (inch), outside diameter of pipe $\mathrm{d}_{\mathrm{p}}$ (inch), density $\rho$ (ppg), flow rate $\mathrm{Q}(\mathrm{gpm})$, apparent viscosity $\mu$ (cP).

\section{Determination of wettability property}

Wettability is a fundamental property of the interactions between the reservoir rock components and the pore filling fluids. Wettability is a controlling factor on the location of the reservoir fluids within its porous structure and upon the flow and subsequent distribution of fluids during the dynamic process of production (McPhee, 2015). The sessile drop method is measured by a contact angle goniometer (Fig. 6) using an optical subsystem to capture the profile of a pure liquid on a solid substrate changing. 


\section{Cleaning efficiency test of KV-MA}

The computational of cleaning efficiency is performed by using a Laboratory Accurate Electric Stirrer/Mixer (Fig. 7A). The SWB containing a simulated oil-based filtercake is set with spindle shaft and the designed KV-MA solution is heated at a temperature of $140^{\circ} \mathrm{F}-160^{\circ} \mathrm{F}$ to enhance chemical reactions for better cleaning performance. The cleaning efficiency is then calculated by Eq. (9) below; whereby weight of SWB smeared with oil-based filtercake before treated with KV-MA solution is $\left(\mathrm{W}_{1}\right)$, weight of SWB smeared with oil-based filtercake after employing KV-MA $\left(\mathrm{W}_{2}\right)$, and the weight of clean SWB is $\left(\mathrm{W}_{0}\right)$.

$\varepsilon=\left(\frac{\mathrm{W}_{1}-\mathrm{W}_{2}}{\mathrm{~W}_{1}-\mathrm{W}_{0}}\right) \times 100 \%$

\section{Results and discussion}

\section{Rheological properties of KV-MA}

\section{Shear stress $(\gamma)$ shear rate $(\tau)$ and apparent viscosity}

The shear rate and shear stress were calculated by using the above Eqs. 1 and 2 as well as correlation of $1 \mathrm{r} / \mathrm{min}$ $(\mathrm{rpm})=1.703 \mathrm{~s}^{-1}$. The experimental data obtained are shown in Table 1 below.

The apparent viscosity of the sample fluid tends to decrease greatly with increasing shear rate. On the other hand, viscosity is observed to increase as the shear rate decreases again (Fig. 8). As the shear rate affects the viscosity of the fluid, thus the shear rate can be used to predict the pumping pressure during the operations (design of the project) only at the shear rate at which it was measured (Caenn et al. 2017).

Table 1 Viscosity Results for a KV-MA in relation to shear rate and shear stress

\begin{tabular}{|c|c|c|c|c|}
\hline \multicolumn{2}{|l|}{ Raw data } & \multicolumn{3}{|l|}{ Interpretation } \\
\hline $\begin{array}{l}\text { Rotor } \\
\text { speed (r/ } \\
\text { min) }\end{array}$ & $\begin{array}{l}\text { Dial reading } \\
\omega\left(\mathrm{lb} / 100 \mathrm{ft}^{2}\right)\end{array}$ & shear rate $\tau\left(\mathrm{s}^{-1}\right)$ & $\begin{array}{l}\text { Shear } \\
\text { stress } \gamma \\
(\mathrm{Pa})\end{array}$ & $\begin{array}{l}\text { Viscosity } \\
\mu(\mathrm{mPa} \bullet \mathrm{s})\end{array}$ \\
\hline 600 & 10 & 1,022 & 5.10 & 5 \\
\hline 300 & 8 & 511 & 4.08 & 8 \\
\hline 200 & 6.5 & 341 & 3.32 & 10 \\
\hline 100 & 4.6 & 170 & 2.35 & 14 \\
\hline 6 & 2.4 & 10 & 1.22 & 120 \\
\hline 3 & 1.5 & 5 & 0.77 & 150 \\
\hline
\end{tabular}

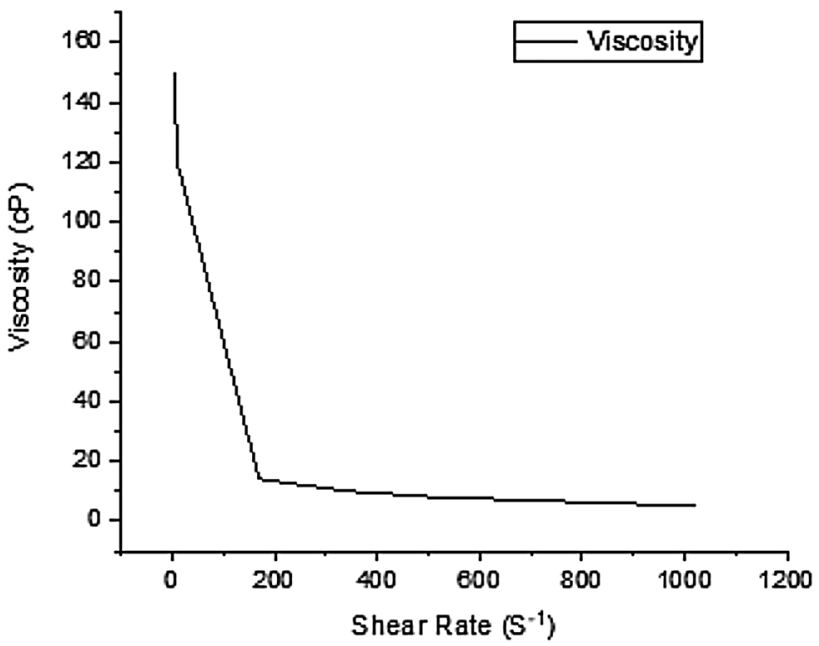

Fig. 8 The influence of shear rate on viscosity of KV-MA solution

\section{Plastic viscosity (PV) and yield stress or point (YP)}

The calculated plastic viscosity and Yield Stress of KV-MA solution are given in Table 2 below,

The plastic viscosity of the designed KV-MA solution was found to be $2 \mathrm{mPa} \bullet$ s. The chemical washes tend to cause a strong filtercake dispersion as they are efficient when they flow in a turbulent flow regime because of their low plastic viscosity values (Xu et al. 2019). The yield point of KV-MA was $6 \mathrm{lb} / 100 \mathrm{ft}^{2}$ as resistance of initial flow of fluid or the stress required in order to move the fluid. This is can therefore be used to determine the pumping pressure of the fluid (KV-MA) during the drilling operations. In addition, it reflects the flow state of fluid during displacement process in the annulus.

Table 2 Results for Plastic Viscosity, Yield Point and Apparent Viscosity of KV-MA

\begin{tabular}{lllll}
\hline Solution & $\begin{array}{l}\text { Density }(\mathrm{Kg} / \\
\left.\mathrm{m}^{3}\right)\end{array}$ & $\begin{array}{l}\text { Plastic } \\
\text { viscosity PV } \\
(\mathrm{mPa} \bullet \mathrm{s})\end{array}$ & $\begin{array}{l}\text { Yield } \\
\text { point YP } \\
\left(\mathrm{lb} / 100 \mathrm{ft}^{2}\right)\end{array}$ & $\begin{array}{l}\text { Apparent } \\
\text { viscosity AV } \\
(\mathrm{mPa})\end{array}$ \\
\hline $\mathrm{KV}$-MA & 1020 & 2 & 6 & 8 \\
\hline & & & \\
\hline
\end{tabular}


Table 3 Results for Reynolds Number $\left(R_{e}\right)$ for the KV-MA

\begin{tabular}{lllllll}
\hline Fluid & Density $\rho(\mathrm{ppg})$ & $\mathrm{d}_{1}(\mathrm{in})$ & $\mathrm{d}_{2}(\mathrm{in})$ & $\mathrm{Q}(\mathrm{gpm})$ & $\mathrm{AV}(\mathrm{cP})$ & $\mathrm{Re}$ \\
\hline KV-MA & 8.6 & 8.65 & 5.5 & 315 & 8 & 9,068 \\
\hline
\end{tabular}

\section{Determination of flow regime}

The Reynolds number were calculated by using given field data of density $\rho$ ( $8.6 \mathrm{ppg}$ ), flow rate Q (315 gpm), hole or casing diameter, $d_{h}\left(5.5\right.$ in), outside diameter of pipe $d_{p}$ (8.65 in), apparent viscosity $\mu_{a}(8 \mathrm{cP})$ and Eq. 8 above and the results are given in Table 3 ,

According to the results in Table 3, the Reynold number $\left(R_{e}\right)$ for the KV-MA was determined to be 9,068 . Because $R_{e}$ is greater than 4000 , the flow regime in the wellbore is turbulent. This type of flow facilitates the removal of the embedded in situ filtercake particles from the wellbore surface, thereby improving cleaning efficiency. During the drilling operations, advancing fluids such as KV-MA solution are required to be pumped turbulently to improve the efficiency of mud and filtercake removal while leaving the casing column and the surface of rock formation water-wet in order to improve the binding ability of the injected cement slurry (Blaz et al. 2017; Nelson 1990; McLean et al. 1967).

\section{Determination of wettability property of KV-MA}

In order to evaluate the wettability property of the designed alkali-surfactant solution (KV-MA) the contact angle was determined using the sessile water drop method through a contact angle goniometer. The two flat polished glass plates were thoroughly cleaned and treated on their surfaces with the oil-based filtercake and placed in a cell one after the other. The KV-MA solution was applied at the surface of one plate. A droplet of water was then deposited by a syringe and brought into contact with the oily-surface plate surface and allowed to age on the sample surface. A high-resolution camera captured the image which was then analyzed using image analysis software. For blank test, drop of water was injected to oily-surface and contact angle was measured by the same procedure.

When the drop of water touched the oil-wet surface which had not been treated with KV-MA solution, it did not spread evenly over the oily-wet surface (Fig. 9A), resulting in a contact angle of $91^{\circ}$. This indicates that the surface energy/ surface tension at the interface of water and oily molecules is extremely high, and thus they cannot interact. When KV-MA solution was applied/injected, it was observed that the applied water drops spread evenly over the oily-phase (Fig. 9B), resulting in a $14^{\circ}$ measure contact angle at that point. There are two mechanisms of wettability alteration by surfactant; the first is the removal of the oil-wet layer exposing the underlying originally water-wet surfaces (cationic), while the second is formation of a water-wet layer over the oil-wet layer (anionic) (Standnes et al. 2000). As a result, the KV-MA solution demonstrated the ability to consistently reverse an oil-wet phase to a water-wet phase as shown in Fig. 10a and b.

The oily-phase film complicates the filtercake removal processes. Due to its chemical nature, oil tends to coat other filtercake composition such as weighting materials and act as a dissolution inhibitor during the cleaning stages (Mohamed et al. 2019; Elkatatny 2019). Wettability alteration of the oil-weighting additive water system is needed prior to treatment (Davidson et al. 2006). The resulted contact angle $14^{\circ}$ reveals the surface has been turned to water-wet from oily-wet. This good water-wetting condition indicates that the filtercake can easily be removed from the wellbore wall surface paving the way to increase of permeability, that is allowing water molecules to penetrate in-between oil and solids surfaces, causing the oily particles to spontaneously repel from the hydrophilic solid surfaces. In addition, during the cementing job, the wall surface will be in a good condition to interact with cement slurry components making a complete hydration process which lead to improvement of bonding strength between cement sheath and formation interface.

\section{Compatibility test o KV-MA}

From the conducted experiments, it was observed that the designed KV-MA solution did not form any precipitates upon the interaction with the oil-based filtercake (Fig. 11
Table 4 Cleaning efficiency test results for KV-MA

\begin{tabular}{llllllll}
\hline Test & Test $(\mathrm{min})$ & Speed $(\mathrm{rpm})$ & $\mathrm{W}_{1}(\mathrm{~g})$ & $\mathrm{W}_{2}(\mathrm{~g})$ & $\mathrm{W}_{0}(\mathrm{~g})$ & $\varepsilon \%$ & Average $\varepsilon / \%$ \\
\hline 1 & 10 & 600 & 547.05 & 546.01 & 545.85 & 86.7 & \\
2 & 10 & 600 & 547.04 & 546.02 & 545.85 & 85.7 & 86.9 \\
3 & 10 & 600 & 547.06 & 546.00 & 545.86 & 88.3 & \\
\hline
\end{tabular}


Fig. 9 Water drop on untreated oily-wet surface (A), and Dispersed water on the treated oily-wet surface $(\mathbf{B})$
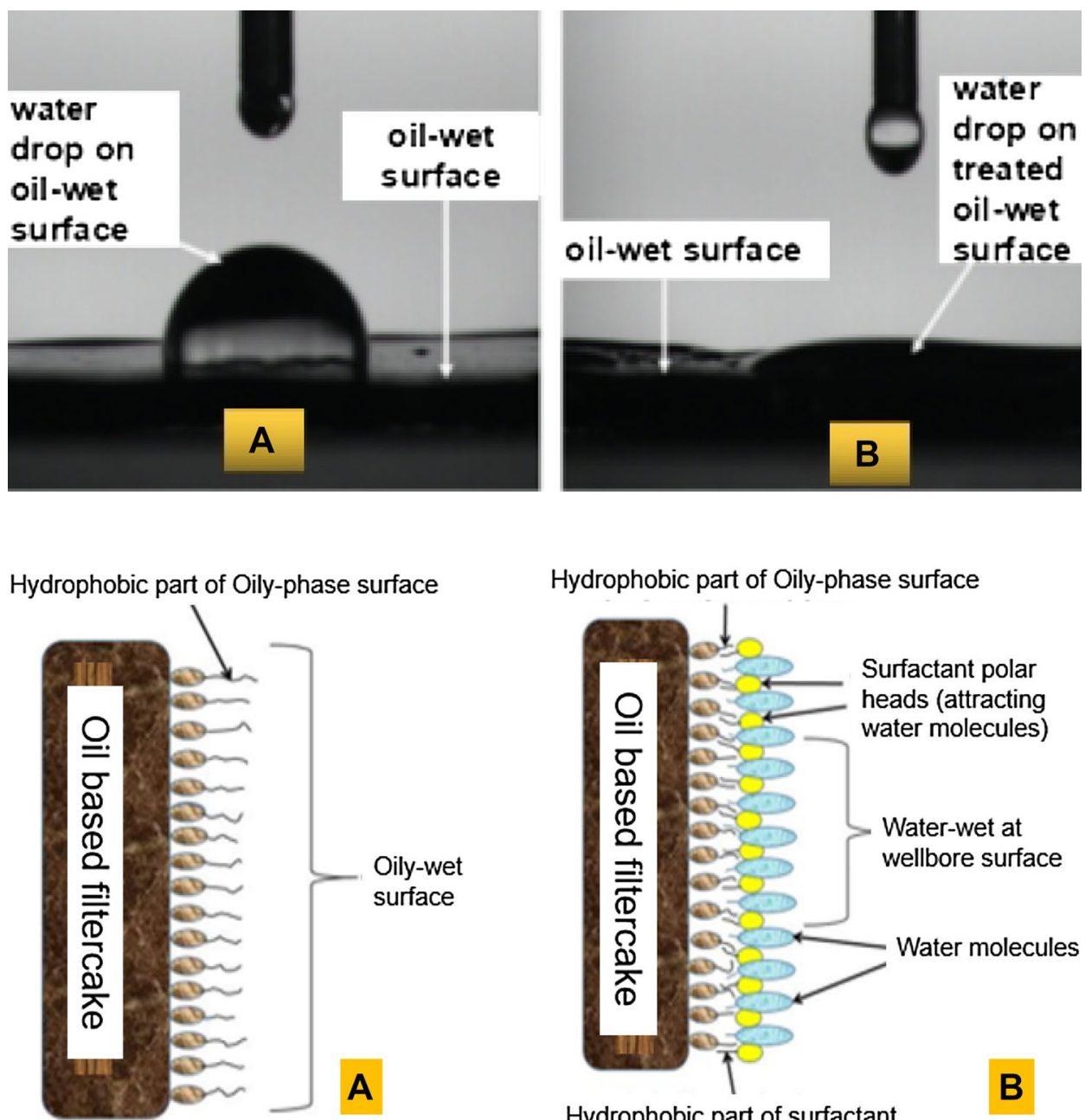

Hydrophobic part of Oily-phase surface

Fig. 10 Oily-wet phase of oil-based filtercake (a) and Wettability reversal from oil-wet to water-wet by KV-MA solution (b)
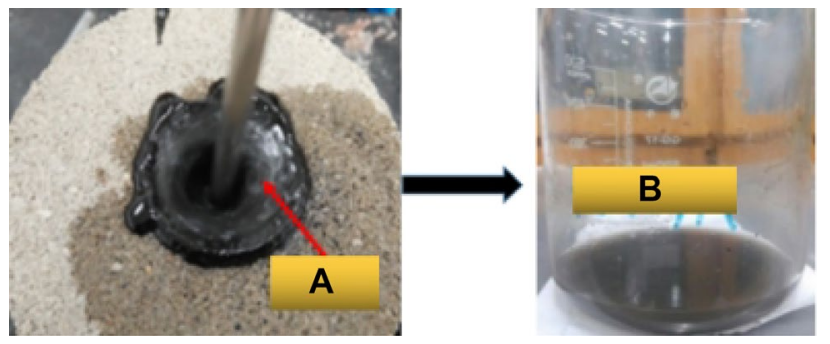

Fig. 11 KV-MA is cleaning wellbore (A), The chunky solution of fine filtercake particles after cleaning test (B) by using electric stirrer/ mixer. (Compatibility test)

$\mathrm{A} \& \mathrm{~B})$; hence, the solution was found to be compatible with the oil-based filtercake.

\section{Cleaning efficiency test of KV-MA}

The cleaning efficiency was computed using a Laboratory Accurate Electric Stirrer/Mixer (Fig. 7A), in which
KV-MA solution was poured into the SWB borehole and waited for 2 min before being stirred continuously for $10 \mathrm{~min}$ at $2000 \mathrm{rpm}$ before being poured out. The cleaning efficiency tests were obtained by using Eq. (9) above, and the efficiency was determined to be $86.9 \%$, which is more effective for proper mud removal. Figure 11, depicts the mud removal efficiency test of the KV-MA to remove the oil-based filtercake and the results are shown in Table 4 below,

\section{Mechanism reaction of KV-MA}

To simulate the filtercake along the wellbore, oil-based mud (drill-in fluid) consisted of diesel oil was used in the experiment. The designed KV-MA solution consisted of a non-ionic surfactant (APG) and alkali $(\mathrm{NaOH})$ to aid the surfactant remove the oily based filtercake particulates on the wellbore surface simulated wellbore (Fig. 12).

The composition of KV-MA solution in the simulated wellbore interacted with oil-based filtercake particles, whereby alkali $(\mathrm{NaOH})$ reacted with a part of naphthenic

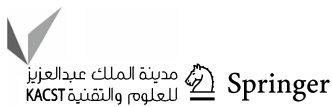


Fig. 12 Simulated wellbore surface before treatment $(\mathbf{A})$ and Simulated wellbore surface after treatment with KV-MA solution $(\mathbf{B})$
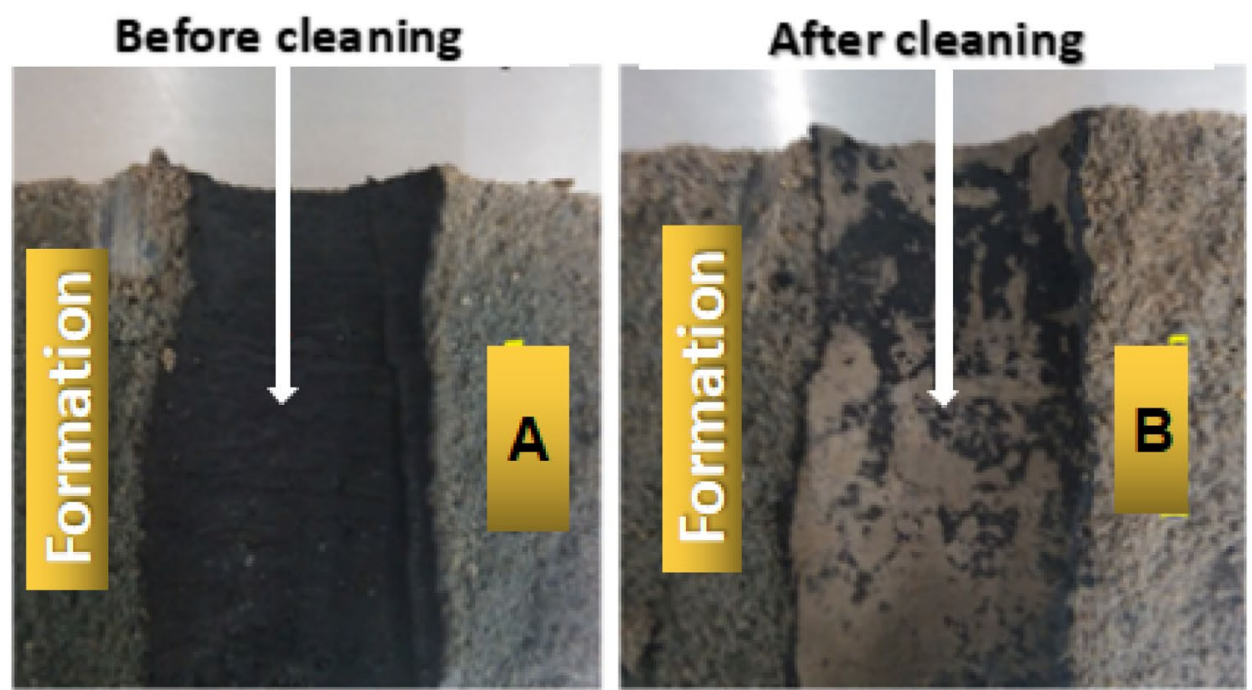

acid groups (as major component of diesel oil) available in the oily-based filtercake to yield additional in situ surfactant Fig. 12. The hydrophobic part of non-ionic surfactant (Alkyl-Polyglycoside) in KV-MA solution interacted with the similar part present in the oily based filtercake pulling them into the flowing alkalialkali-surfactant solution leading to the formation of the in the solution called Oil-in-water emulsion (Fig. 11B), indicating that the chunky, coarse or fine dispersion of oily-filtercake materials are incorporated into the alkali-surfactant solution. The hydration sphere of the surfactant adsorbed onto the wellbore surface prevents the re-buildup of the oily-filtercake along the wall surface particles.

The synergy between the surfactant and alkaline is turned out as follows: $\mathrm{NaOH}$ reacts with the polar components in the oil phase (Fig. 13) of the oil-based filtercake to produce ionized surface-active species; hence reducing the Interfacial
Tension (IFT) to prolong the oily phase. Surfactant quickens the diffusion of ionized species from the interface to the bulk phase, and then the polar components underneath is exposed to $\mathrm{NaOH}$; therefore, the reaction between $\mathrm{NaOH}$ and polar oily phase components can proceed to further reduce the IFT (Zhang et al. 2012).

The combination of alkaline and surfactant reduced IFT more rapidly than alkaline or surfactant alone whereby the time required to meet the minimum IFT for $\mathrm{NaOH}$ solution was longer than that for $\mathrm{NaOH} /$ surfactant mixtures (Touhami et al. 1998). This means that IFT is lowered more significantly by chemical reaction than by adding ready-made surfactant below the critical micelle concentration (CMC); the dynamic IFT behavior is dampened by adding the surfactant above the CMC. For the coeffect of alkaline and surfactant, it can reduce the IFT of O/W to an ultralow level (Zhang et al. 2010). Some authors suggested that the synergistic
Fig. 13 Reaction of alkali with organic acid in oily based filtercake to form in situ surface-active agent (Lichinga et al. 2019)<smiles>CCC1CC(CCC(=O)O)C(CCC(=O)O[NH3+])[C@H]1C(=O)O[Na]</smiles> 


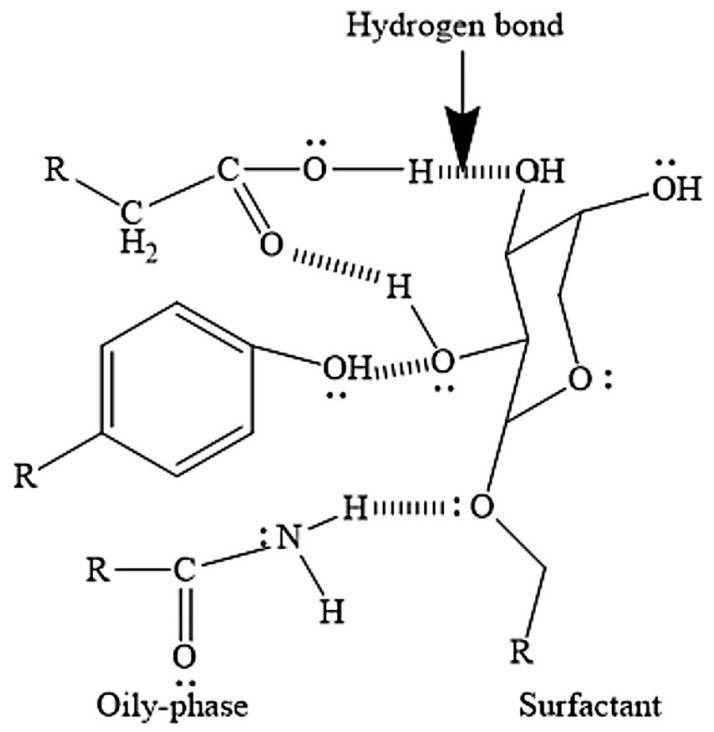

Fig. 14 Non-ionic surfactant molecules adsorb at oily-phase molecules by hydrogen bond

effect resulting from both alkaline and surfactant reduces the IFT more effectively (Liu et al. 2005).

The KV-MA solution contains a non-ionic surfactant (alkyl polygycoside) with a carbon number ranging from 14 to 16, presenting a suitable Hydrophile Lipophile Balance (HLB) of 9.5 to 10.5. As shown in Fig. 14, its hydrophobic part is drawn toward similar parts of the oily-phase molecules by Van der Waal Forces and adsorbs at the oily-phase surface by hydrogen bond (Zhang et al. 2002). In this case, a polar part of the surfactant (hydrophilic) attracts polar water molecules to the oily-phase surface, converting the surface from oil-wet (Fig. 10a) to water-wet (Fig. 10b), which is easily swept away.

The alkyl polyglycoside (APG) surfactant as non-ionic in nature, tend to utilize its many hydroxyl groups in the polysaccharide chain to achieve hydrophilicity, in combination with alkali materials $\left(\mathrm{Na}^{+}, \mathrm{OH}^{-}\right)$has effectively cleaned oil-based filtercake along the wellbore surface by lowering the surface tension. This means that the oil soluble portion (hydrophobic) of APG surfactant is controlled by the alkyl chain length varied from $\mathrm{C} 14$ to $\mathrm{C} 16$, whereby each saccharide group is typically equivalent to 5-7 ethylene oxide groups, and therefore is very effective in forming water-soluble properties to APG surfactant even at high salinity and hardness conditions such as found in seawater (Chan 1991).

The obtained low contact angle as a result of KV-MA solution, indicated that the surface is high wetting, which led to low surface tension and thus making the oil-based filtercake to be readily dissolved and emulsified by the KV-MA solution.

\section{Conclusions}

Based on the experimental results, the following firm conclusions are drawn;

1. The oil-based filtercake particles are mostly dispersed and water-wetted by KV-MA solution. The oil-based fluid is compatible with designed KV-MA solution since no precipitates were observed in the mixture solution

2. The KV-MA solution is an effective chemical with cleaning efficiency of $86.9 \%$. This indicates that the solution can effectively clean the wellbore surface hence enhanced oil well productivity. The solution permeated into oily based filtercake material breaking and pulling them into the flowing alkali-surfactant solution leading to the formation of Oil-in-water emulsion, visualized as chunky, coarse or fine dispersion of oily-filtercake materials which are incorporated into the alkali-surfactant solution.

3. The resulted contact angle $14^{\circ}$ reveals the surface has been turned to water-wet from oily-wet. This good water-wetting condition indicates that the filtercake can easily be removed from the wellbore wall surface paving the way to increase of permeability, that is allowing water molecules to penetrate in-between oil and solids surfaces, causing the oily particles to spontaneously repel from the hydrophilic solid surfaces.

4. The synergy between the surfactant and alkaline is turned out as $\mathrm{NaOH}$ reacts with the polar components in the oil phase of the oil-based filtercake to produce ionized surface-active species; hence reducing the Interfacial Tension (IFT) to prolong the oily phase. Surfactant quickens the diffusion of ionized species from the interface to the bulk phase, and then the polar components underneath is exposed to $\mathrm{NaOH}$.

5. The results indicated that the KV-MA solution, prevailed a Reynold number of 9068. As the Reynold number is greater than 4000 , this suggests that the flow regime in the annulus is turbulent. Advancing fluids such as KV-MA solution are required to be pumped turbulently to improve the efficiency of mud and filtercake removal while leaving the casing column and the surface of rock formation water-wet in order to improve the binding ability of the injected cement slurry.

Supplementary Information The online version contains supplementary material available at https://doi.org/10.1007/s13202-021-01438-1. 
Acknowledgements Authors extend appreciation to the Tanzania Industrial Research and Development Organization (TIRDO), Department of Chemistry, College of Natural and Mathematical Sciences, The University of Dodoma (UDOM), Dodoma-Tanzania and Department of Petroleum Engineering, Faculty of Earth Resources for Oil Well Cement Research and Testing, No. 388, Lumo Road, Hongshan District, Wuhan, China University of Geosciences, Wuhan, 430074, PR China.

Funding No funding agent.

\section{Declarations}

Conflicts of interest The authors declare no conflict of interest.

Open Access This article is licensed under a Creative Commons Attribution 4.0 International License, which permits use, sharing, adaptation, distribution and reproduction in any medium or format, as long as you give appropriate credit to the original author(s) and the source, provide a link to the Creative Commons licence, and indicate if changes were made. The images or other third party material in this article are included in the article's Creative Commons licence, unless indicated otherwise in a credit line to the material. If material is not included in the article's Creative Commons licence and your intended use is not permitted by statutory regulation or exceeds the permitted use, you will need to obtain permission directly from the copyright holder. To view a copy of this licence, visit http://creativecommons.org/licenses/by/4.0/.

\section{References}

Abraham J, Sharika T, Mishra RK, Thomas S (2017) 14 - Rheological characteristics of nanomaterials and nanocomposites. Woodhead Publishing, Sawston

Agbasimalo N, Radonjic M (2014) Experimental study of the impact of drilling fluid contamination on the integrity of cement-formation interface. J Energy Resour Technol 136(4):042908. https:// doi.org/10.1115/1.4027566

Almond SW, Harris RE, Penny GS (1995) Utilization of biologically Generated acid for drilling fluid damage removal and uniform acid placement across long formation interval. Paper SPE 30123, presented at the European Formation Damage Conference, Hague, The Nertherland, 15-16 May

Al-Otaibi MB, Nasr-El-Din HA, Siddiqui MA (2004a) Wellbore cleanup by water jetting and specifc enzyme treatments in multilateral wells: a case study. Soc Pet Eng. https://doi.org/10.2118/ 87206-MS

Al-Otaibi MB, Nasr-El-Din HA, Siddiqui MA (2004b) Wellbore cleanup by water jetting and specifc enzyme treatments in multilateral wells: a case study. In: Paper IADC/SPE 87206 presented at the IADEC/SPE drilling conference. Dallas. https://doi.org/10. 2118/87026-MS

Al-Otaibi MA, BinMoqbil KH, Al-Rabba AS, Abitrabi AN (2010) Single-stage chemical treatment for oil-based filtercake cleanup: field case and laboratory studies. In: Paper presented at the SPE International Symposium and Exhibition on Formation Damage Control, Lafayette, Louisiana, USA, February 2010. doi: https:// doi.org/10.2118/127795-MS

Błaz S (2017) Nowe rodzaje cieczy przemywaj acych osady z płuczki inwersyjnej przed zabiegiem cementowania otwor 'ów wiertniczych (ang. New types of preflush fluids removing invert emulsion drilling mud filter cake prior to casing cementing). Nafta-Gaz 73:302-311

Burnham P, Dollahon N, Li CH, Viescas AJ, Papaefthymiou GC (2013) Magnetization and specific absorption rate studies of ball-milled iron oxide nanoparticles for biomedicine. J Nanoparticles 2013:1-13. https://doi.org/10.1155/2013/181820

Caenn R, Darley HCH, Gray GR (2017) Introduction to drilling fluids. Compos Prop Drilling Complet Fluids. https://doi.org/10. 1016/b978-0-12-804751-4.00001-8

Chan AF, Ly KT, Richardson (1998) Surfactant blends for well operations (U.S. Patent No. 5,830,831). U.S. Patent and Trademark Office. https://patentimages.storage.googleapis.com/cc/e9/54/ 5b4c512921d046/US5830831.pdf

Chan M, Yen TF (1981) Role of sodium chloride in the lowering of interfacial tension between crude oil and alkaline aqueous solution. Fuel 60:552-553

Chan M, Yen TF (1982) A chemical equilibrium model for interfacial activity of crude oil in aqueous alkaline solution: the effects of pH, alkali and salt. Can J Chem Eng 60:305-308

Chan AF (1991) Well cleanout using caustic alkyl polyglycoside compositions. CA2099012C (en). https://patents.google.com/ patent/WO1992014031A1/en

Chatterjee J, Wasan DT (1998) A kinetic model for dynamic interfacial tension variation in an acidic oil/alkali/surfactant system. Chem Eng Sci 53:2711-2725

Davidson E, McMillan DN, Martin F, Morton K, Lenz R (2006) Successful deployment of a new stimulation chemical, post horizontal open-hole gravel pack in wells drilled with both water-based and oil-based drill-in fluid. In Proceedings of the SPE/IADC Indian Drilling Technology Conference and Exhibition, Mumbai, India, 16-18 October 2006

Ding Y, Herzhaft B, Renard Gd (2006) Near-wellbore formation damage effects on well performance-A comparison between underbalanced and overbalanced drilling. SPE Prod Oper 21:51-57. https://doi.org/10.2118/86558-PA

Drilling muds (2015) Petroleum engineer's guide to oil field chemicals and fluids, pp 1-61. https://doi.org/10.1016/b978-0-12-803734-8. 00001-1

El Sukkary MMA et al (2008) Synthesis and characterization of some alkyl polyglycosides surfactants. J Surfactants Deterg 11(2): 129-137

Elkatatny S (2019) One-stage calcium carbonate oil-based filter cake removal using a new biodegradable acid system. Sustainability 11:5715

Federal Register. Annular casing pressure management for offshore wells (Final Rule), p. 23582, May 4, 2010 (2010)

Fontenot JE, Simpson JP (1998) A microbit investigation of the potential for improving the drilling rate of oil-base muds in low-permeability rocks. Soc Petrol Eng 26(5):507-509. https://doi.org/ 10.2118/4519-PA

Gandhi SM, Sarkar BC (2016) Drilling. In: Essentials of mineral exploration and evaluation, pp 199-234. https://doi.org/10.1016/b9780-12-805329-4.00015-6

Gbadamosi AO, Junin R, Manan MA, Agi A, Yusuff AS (2019) An overview of chemical enhanced oil recovery: recent advances and prospects. Int Nano Lett 9:171-202. https://doi.org/10.1007/ s40089-019-0272-8

Gu J, Huang J, Gao H et al (2015) Solidifying mud cake to improve cementing quality of shale gas well: a case study. Open Fuels Energy Sci J 8(1):149-154. https://doi.org/10.2174/1876973X01 508010149

Guo J, Liu Q, Li M, Wu Z, Christy AA (2005) The effect of alkali on crude oil/water interfacial properties and the stability of crude oil emulsions. Colloid Surf A 273(1-3):213-218 
Binmoqbil KH, Al-Otaibi MA, Al-Faifi MG, Al-Khudair WS, AlAamri AD (2009) Cleanup of oil-based mud filter cake using an in-situ acid generator system by a single-stage treatment. Paper presented at the SPE Saudi Arabia Section Technical Symposium, Al-Khobar, Saudi Arabia, May 2009. doi: https://doi.org/10.2118/ 126065-MS

Kiran R, Teodoriu C, Dadmohammadi Y, Nygaard R, Wood D, Mokhtari M, Salehi S (2017) Identification and evaluation of well integrity and causes of failure of well integrity barriers (A review). J Nat Gas Sci Eng. https://doi.org/10.1016/j.jngse.2017. 05.009

Kume G, Gallotti M, Nunes G (2008) Review on anionic/cationic surfactant mixtures. J Surfactants Deterg 11:1-11. https://doi.org/10. 1007/s11743-007-1047-1

Ladva HKJ, Craster B, Jones TGJ, Goldsmith G, Scott D (2004) The cement-to formation interface in zonal isolation. Soc Pet Eng. https://doi.org/10.2118/88016-MS

Ladva HKJ, Bernadette C, Timothy GJ, Garry G, David S (2005) The cement-to formation interface in zonal isolation. SPE Drill Complet 3:186-197

Leschi P, Demarthon G, Davidson E, Clinch D (2006) Delayed-release acid system for the cleanup of Al Khalij horizontal open hole drains. Paper SPE 98164, prepared for presentation at the SPE International Symposium and Exhibition on Formation Damage Control, Lafayette, Louisiana, 15-17 February

Lichinga KN, Maagi MT, Qinggui W, Hao H, Gu J (2019) Experimental study on oil based mudcake removal and enhancement of shear bond strength at cement-formation interface. J Pet Sci Eng. https:// doi.org/10.1016/j.petrol.2019.01.066

Lichinga KN, Maagi MT, Ntawanga AC, Hao H, Gu J (2020) A novel preflush to improve shear bond strength at cement-formation interface and zonal isolation. J Pet Sci Eng 195:107821. https://doi.org/ 10.1016/j.petrol.2020.107821

Liu Q, Dong M, Yue X, Hou J (2005) Synergy of alkali and surfactant in emulsification of heavy oil in brine. Colloid Surf A 273(1-3):219-228

Malone MR, Nelson SG, Jackson R (2000) Enzyme breaker technology increase production, grayburg-jackson feld, southeast New Mexico: a case history. In: Paper SPE 59709 Presented at the SPE Permean Basin Oil and Gas Recovery Conference. Midland, Texas. https://doi.org/10.2118/59709-MS

McLean RH, Manry CW, Whitaker WW (1967) Displacement mechanics in primary cementing. J Pet Technol 19:251-260

McPhee C, Reed J, Zubizarreta I (2015) Wettability and wettability tests. Core Anal A Best Pract Guide. https://doi.org/10.1016/ b978-0-444-63533-4.00007-x

Mohamed A, Elkatatny S, Basfar S (2019) One-stage calcium carbonate oil-based filter cake removal using a new biodegradable acid system. In Proceedings of the SPE-198045-MS, SPE Kuwait Oil $\&$ Gas Show and Conference, Mishref, Kuwait, 13-16 October 2019

Moore WR, Beall BB, Syed AA (1996) Formation damage removal through the application of enzyme breaker technology. In: Paper SPE 31084 Presented at the SPE International Symposium on Formation Damage Control Symposium, Lafayette. Louisiana. https://doi.org/10.2118/31084-MS

Mushtaq W (2013) Experimental study of cement-formation bonding. Dissertation, Department of Petroleum Engineering and Applied Geophysics, Norwegian University of Science and Technology. http://hdl.handle.net/11250/240084

Morris BA (2017) 5 - Rheology of polymer melts. In: Morris BA (ed) The science and technology of flexible packaging. Plastics design library. William Andrew Publishing, pp 121-147. ISBN 9780323242738. https://doi.org/10.1016/B978-0-323-24273-8. 00005-8
Nasr-El-Din HA, Samuel M (2007) Lessons Learned from using viscoelastic surfactants in well stimulation Treatments. SPEPO 22(1):112-120

Nasr-El-Din HA, Al-Otaibi MB, et al (2004) An effective fluid formulation to remove drilling fluid mud cake in horizontal and multilateral wells. SPE Drilling \& Completion, 22, SPE-87960-PA

Nasr-El-Din HA, Al-Otaibi MB, et al. (2005) Laboratory studies of insitu generated acid to remove filter cake in gas wells. SPE Annual Technical Conference and Exhibition, Dallas, 9-12 October 2005, SPE-96965-MS

Nelson EB (1990) Well cementing. Schlumberger educational services. Elsevier Science, Amsterdam. ISBN 9780080868868

Ramsey MS (2019a) Chapter three - Hole cleaning. In: Ramsey MS (ed) Gulf drilling guides, practical wellbore hydraulics and hole cleaning. Gulf Professional Publishing, pp 75-115. ISBN 9780128170885. https://doi.org/10.1016/B978-0-12-817088-5. 00003-4

Ramsey MS (2019b) Chapter nine - Appendix. In: Ramsey MS (ed) Gulf drilling guides, practical wellbore hydraulics and hole cleaning. Gulf Professional Publishing, pp 283-310. ISBN 9780128170885. https://doi.org/10.1016/B978-0-12-817088-5. 00009-5

Rostami A, Nasr-EI-Din H (2010) A new technology for filter cake removal. Paper presented at the SPE Russian oil and gas conference and exhibition, Moscow, Russia, October 2010. https://doi. org/10.2118/136400-MS

Rudin J, Wasan DT (1992a) Mechanisms for lowering of interfacial tension in alkali/acidic oil systems 1. Experimental studies. Colloid Surf 68(1-2):67-79. https://doi.org/10.1021/ie00008a010

Rudin J, Wasan DT (1992b) Mechanisms for lowering of interfacial tension in alkali/acidic oil systems 2 . Theoretical studies. Colloid Surf 68:81-94. https://doi.org/10.1021/ie00008a010

Standnes DC, Austad T (2000) Wettability alteration in chalk: 2. mechanism for wettability alteration from oil-wet to water-wet using surfactants. J Pet Sci Eng 28(3):123-43. https://doi.org/10.1016/ S0920-4105(00)00084-X

Sułek MW et al (2013) Alkyl polyglucosides as components of water based lubricants. J Surfactants Deterg 16(3):369-375. https://doi. org/10.1007/s11743-012-1428-y

Taylor KC, Nasr-El-Din HA (1996) The effect of synthetic surfactants on the interfacial behaviour of crude oil/alkali/polymer system. Colloid Surf A 108:49-72. https://doi.org/10.1016/0927-7757(95) 03364-5

Touhami Y, Hornof V, Neale GH (1998) Dynamic interfacial tension behavior of acidified oil/surfactant-enhanced alkaline system 1 . Experimental studies. Colloid Surf A 132:61-74. https://doi.org/ 10.1016/S0927-7757(97)00165-9

Touhami Y, Hornof D, Rana V, Neale GH (2001) Effects of added surfactant on the dynamic interfacial tension behavior of acidic oil/alkaline systems. J Colloid Interface Sci 239:226-229. https:// doi.org/10.1006/jcis.2001.7547

Von Rybinski W, Hill K (1998) Alkyl polyglycosides-properties and applications of a new class of surfactants. Angew Chem Int Ed 37(10):1328-1345

Wang F, Qiu Z, Ding R et al (2001) A new method to remove drilling mud cake in fractured reservoir. Pet Drill Tech 29:29-31

Wei P, Li J, Xie Y, Huang X, Sun L (2020) Alkyl polyglucosides for potential application in oil recovery process: adsorption behavior in sandstones under high temperature and salinity. J Petrol Sci Eng 189:107057. https://doi.org/10.1016/j.petrol.2020.107057

Xu D, Guo J, Yuan B, Wen D, Fang X, Li H, Ling B (2019) A minimum volume prediction of spacer based on turbulent dispersion theory: model and example. Petroleum 5:397-401

Yuan JY, Law DHS, Nasr TN (2002) Benefit of wettability change near the production well in SAGD. Paper presented at the Canadian

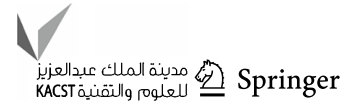


International Petroleum Conference, Calgary, Alberta, June 2002. doi: https://doi.org/10.2118/2002-255

Zain ZM, Sharma MM (1999) Cleanup of wall-building filter cakes. SPE annual technical conference and exhibition, Houston, 3-6 October 1999, SPE-56635-MS

Zhang L, Somasundaran P, Mielczarski J, Mielczarski E (2002) Adsorption mechanism of $n$-dodecyl- $\beta$ - $\alpha$-maltoside in alumina. J Colloid Interface Sci 256:16-22

Zhang H, Dong M, Zhao S (2010) Which one is important in chemical flooding for enhanced Court heavy oil recovery, lower interfacial tension or reducing water mobility. Energy Fuels 24(3):1829-1836

Zhang H, Dong M, Zhao S (2012) Experimental study of the interaction between $\mathrm{NaOH}$, surfactant, and polymer in reducing court heavy oil/brine interfacial tension. Energy Fuels 26(6):36443650. https://doi.org/10.1021/ef300498r

Zhang H, Yang S, Liu D, Li Y, Luo W, Li J (2020) Wellbore cleaning technologies for shale-gas horizontal wells: difficulties and countermeasures. Nat Gas Ind B 7(2):190-195

Publisher's Note Springer Nature remains neutral with regard to jurisdictional claims in published maps and institutional affiliations. 